\title{
A Genealogy of Neoliberal Communitarianism
}

Friso van Houdt, Erasmus University Rotterdam

Willem Schinkel, Erasmus University Rotterdam

\begin{abstract}
This article investigates the power/knowledge relations between contemporary penal government and criminological theory. Based on an analysis of the strategic case of the Netherlands, the emergence of what can be called neoliberal communitarianism is discussed. In relation to the 'penal welfarism' it succeeds, neoliberal communitarianism provides a rationale of governing that allows a greater amount of complexity precisely because it consists of a paradoxical set of doctrines, discourses and techniques. This involves an emphasis on both 'individual responsibility' and 'community', protecting market and community by tightening social control, law and order and the production of rational self-controlling individuals while excluding the cultural and biological 'risk citizen'. The article illustrates the incorporation of criminological theories as policy underpinnings, and it explicates how criminological theories can be placed in the discursive space of neoliberal communitarianism.
\end{abstract}

\section{Keywords}

neoliberalism - communitarianism - prevention - punishment - genealogy

\section{Word length}

8,961

\section{Author contact address}

vanhoudt@fsw.eur.nl 